\title{
Effect of 4-Phenylbutyric Acid and Tauroursodeoxycholic Acid on Magnesium and Calcium Metabolism in Streptozocin-Induced Type 1 Diabetic Mice
}

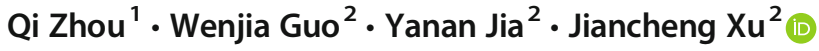

Received: 1 August 2018 / Accepted: 24 August 2018 / Published online: 31 August 2018

(C) The Author(s) 2018

\begin{abstract}
Recent evidence has identified a role of micronutrients, such as magnesium $\left(\mathrm{Mg}^{2+}\right)$ and calcium $\left(\mathrm{Ca}^{2+}\right)$, in glycemic control. 4Phenylbutyric acid (PBA) and tauroursodeoxycholic acid (TUDCA) are molecular chaperones that can improve protein folding and alleviate endoplasmic reticulum (ER) stress. Increasingly, research is focusing on the association between molecular chaperones and micronutrients. This study established and characterized a mouse model of type 1 diabetes (T1D) and investigated the effect of PBA and TUDCA on $\mathrm{Mg}^{2+}$ and $\mathrm{Ca}^{2+}$ metabolism in these mice. T1D was established in Friend virus B-type mice using multiple low doses of streptozotocin. Mice were administered chaperones. $\mathrm{Mg}^{2+}$ and $\mathrm{Ca}^{2+}$ levels in tissues and serum were detected using acid digestion and ICP-MS. At 2 weeks and 2 months after chaperone administration was initiated, $\mathrm{Mg}^{2+}$ levels in the heart, liver, kidney, and serum and $\mathrm{Ca}^{2+}$ levels in spleen and serum of T1D mice were significantly decreased compared with controls; $\mathrm{Ca}^{2+}$ levels in the kidney and muscle of T1D mice were significantly increased; $\mathrm{Mg}^{2+}$ and $\mathrm{Ca}^{2+}$ levels in the heart, liver, kidney, muscle, spleen, and serum were positively correlated in control and T1D mice; and PBA restored renal $\mathrm{Mg}^{2+}$ levels to normal values and TUDCA restored hepatic, renal, and serum $\mathrm{Mg}^{2+}$ levels and renal and serum $\mathrm{Ca}^{2+}$ levels to normal values in T1D mice. PBA restored muscular $\mathrm{Ca}^{2+}$ levels to normal values in T1D mice at 2 months after chaperone or vehicle administration was initiated. Further research is required to investigate the underlying mechanisms by which chaperones regulate micronutrients in diabetes.
\end{abstract}

Keywords Magnesium $\cdot$ Calcium $\cdot$ Diabetes $\cdot 4$-Phenylbutyric acid $\cdot$ Tauroursodeoxycholic acid

\section{Introduction}

Globally, non-communicable diseases (NCDs), including cardiovascular disease, diabetes mellitus, cancer, and chronic respiratory diseases [1], are associated with substantial morbidity and mortality. In particular, diabetes is a growing public health concern, with prevalence increasing in developing countries [2,3]. Diabetes can cause complications in multiple organs, manifesting as diabetic retinopathy, neuropathy, and nephropathy and causing disability and mortality in many individuals [4]. Type 1 diabetes (T1D) is characterized by

Jiancheng Xu

jianchengxu@yeah.net

1 Department of Pediatrics, First Hospital of Jilin University, Changchun 130021, China

2 Department of Laboratory Medicine, First Hospital of Jilin University, 71 Xinmin Street, Changchun 130021, China hyperglycemia resulting from autoimmune destruction of insulin-secreting pancreatic $\beta$-islet cells.

Nutrition is a critical component of diabetes management. Previously, interest in the role of nutrients in diabetes has focused on macronutrients, including carbohydrate and fat. More recent evidence has identified a role for micronutrients, such as magnesium $\left(\mathrm{Mg}^{2+}\right)$ [5] and calcium $\left(\mathrm{Ca}^{2+}\right)$ [6], in glycemic control. $\mathrm{Mg}^{2+}$ is the most abundant divalent intracellular cation, the second most abundant intracellular ion, and the fourth most abundant mineral in the human body [7]. Some studies show that $\mathrm{Mg}^{2+}$ may improve insulin sensitivity and prevent diabetes [8]; however, two cohort studies (13,076 persons/year) indicated that low $\mathrm{Mg}^{2+}$ intake was not a risk factor for diabetes [9], and six randomized controlled trials demonstrated that $\mathrm{Mg}^{2+}$ was not effective for glycemic control in patients with type 2 diabetes (T2D) [9]. $\mathrm{Ca}^{2+}$ is the most abundant ion in the body. Alterations in $\mathrm{Ca}^{2+}$ homeostasis are associated with organelle dysfunction and stress responses in metabolic organs such as liver and adipose tissue [6]. Both T1D and T2D are characterized by changes in $\mathrm{Ca}^{2+}$ and bone 
metabolism, in part due to impaired $\mathrm{Ca}^{2+}$ absorption from intestine [10]. According to our previous studies [11, 12], diabetes induces endoplasmic reticulum stress (ERS) and vice versa; the effect on trace elements, especially on $\mathrm{Ca}^{2+}$, is quite clear.

Chemical or drug chaperones, including 4-phenylbutyric acid (PBA) and tauroursodeoxycholic acid (TUDCA), can improve protein folding and lessen ERS. Increasingly, research is focusing on the association between molecular chaperones and micronutrients. In a mouse model of chronic kidney disease, short-term treatment with TUDCA normalized $\mathrm{Ca}^{2+}$ content in vascular smooth muscle, providing a potential strategy for therapeutic management of vascular calcification [13]. In HeLa human cervical cancer cells, propofol-induced disruption of intracellular $\mathrm{Ca}^{2+}$ balance was inhibited by TUDCA [14]. In vascular smooth muscle cells, the Runx2 expression, alkaline phosphatase activity, and $\mathrm{Ca}^{2+}$ nodules induced by high concentrations of glucose were decreased by PBA pretreatment [15]. In a rat model of severe burn injury, PBA treatment prevented swelling of ER, changed the expression of ERS markers and $\mathrm{Ca}^{2+}$ release, and reduced calpain activation and skeletal muscle damage/wasting [16].

Currently, reports on effects of PBA or TUDCA on $\mathrm{Mg}^{2+}$ and $\mathrm{Ca}^{2+}$ metabolism in diabetes are scarce. This study established and characterized a mouse model of T1D and investigated the effect of PBA and TUDCA on $\mathrm{Mg}^{2+}$ and $\mathrm{Ca}^{2+}$ metabolism in these mice.

\section{Materials and Methods}

\section{Animal Models}

Eight-week-old, male Friend virus B-type (FVB) mice purchased from Vital River Laboratories (Beijing, China) were housed at the Experimental Animal Center in the College of Basic Medical Sciences, Jilin University. Mice were maintained at $22^{\circ} \mathrm{C}$ with a 12 -h light/dark cycle and were provided free access to standard rodent chow and water. This study was approved by the institutional ethics committee of the First Hospital of Jilin University.

Mice were randomly divided into six groups: non-diabetic control mice $(\mathrm{CON})$; diabetic mice $(\mathrm{DM})$; diabetic mice treated with PBA $(\mathrm{PBA}+\mathrm{DM})$; diabetic mice treated with TUDCA (TUDCA + DM); non-diabetic control mice treated with PBA (PBA); and non-diabetic control mice treated with TUDCA (TUDCA). Mice in all groups were fed with standard laboratory chow (Mouse Feed Food, no. 8061, Chengdu Dashuo Laboratory Animal Co., Ltd., Chengdu, China), which contained $18 \%$ protein, $4 \%$ fat, $5 \%$ fiber, $10 \%$ ash content, and $1.4 \% \mathrm{Ca}$.

T1D was induced in mice with streptozotocin (STZ) (Sigma Chemical Co., St. Louis, MO, USA) dissolved in sodium citrate buffer ( $\mathrm{pH} 4.5$ ) administered intraperitoneally at $40 \mathrm{mg} / \mathrm{kg}$ body weight daily for 5 days (multiple low-dose STZ [MLD-STZ] model). After the very last injection of STZ on the 5th day, blood glucose obtained from the tail-vein was measured using a Glucometer (Bayer HealthCare, Mishawaka, IN, USA). STZ-treated mice with fasting blood glucose $>12 \mathrm{mmol} / \mathrm{L}$ were considered diabetic [11].

Diabetic mice were acclimatized to PBA or TUDCA by pretreatment with $100 \mu \mathrm{L}$ PBA (Merck KGaA, Hohenbrunn, Germany) in drinking water daily or $100 \mu \mathrm{L}$ TUDCA (Calbiochem, La Jolla, CA, USA) by intraperitoneal injection twice each day ( 8 am and 8 $\mathrm{pm})$. After 3 days, at $8 \mathrm{am}$, fasting blood glucose obtained from the tail-vein was measured, and chaperone or vehicle administration was initiated (time $=$ day 0$)$. PBA was administered by gavage $(500 \mathrm{mg} / \mathrm{kg}$ at 8 am and $8 \mathrm{pm}$, total $1 \mathrm{~g} / \mathrm{kg} /$ day), and TUDCA was administered intraperitoneally $(250 \mathrm{mg} / \mathrm{kg}$ at $8 \mathrm{am}$ and $8 \mathrm{pm}$, total $500 \mathrm{mg} / \mathrm{kg} /$ day $)$, in divided doses daily. Controls for PBA- or TUDCAtreated diabetic mice were administered the same volume of vehicle by gavage or intraperitoneal injection, respectively. Fasting blood glucose and body weight were monitored regularly.

Mice were sacrificed at 2 weeks and 2 months after treatment initiation with PBA or TUDCA using $2 \%$ sodium pentobarbital $(30 \mathrm{mg} / \mathrm{kg}$, intraperitoneal) and cardiac puncture. The heart, liver, kidney, spleen, and soleus muscles were removed and stored at $-80^{\circ} \mathrm{C}$ before processing. Blood was collected into metal-free tubes for analysis of biochemical parameters or $\mathrm{Mg}^{2+}$ and $\mathrm{Ca}^{2+}$ levels, respectively. Blood was centrifuged at $12000 \mathrm{r} / \mathrm{min}$ and $4{ }^{\circ} \mathrm{C}$ for $5 \mathrm{~min}$. Serum was aliquoted into Eppendorf tubes soaked in $10 \%(w / w)$ nitric acid, shock frozen, and stored at $-80^{\circ} \mathrm{C}$ until further analysis.

\section{Determination of $\mathrm{Mg}^{2+}$ and $\mathrm{Ca}^{2+}$ by Acid Digestion Followed by ICP-MS}

Preweighed samples of the heart, liver, kidney, soleus muscle, and spleen were digested in $5 \mathrm{~mL}$ nitric acid at room temperature for $12 \mathrm{~h}$ and at $110{ }^{\circ} \mathrm{C}$ for $8 \mathrm{~h} .0 .5 \mathrm{~mL}$ serum were digested in $2 \mathrm{~mL} 10 \%$ nitric acid at room temperature for $30 \mathrm{~min}$. Subsequently, serum was digested at $100{ }^{\circ} \mathrm{C}$ for $2 \mathrm{~h}$. Deionized water was added to each sample to increase the volume to $15 \mathrm{~mL} . \mathrm{Mg}^{2+}$ and $\mathrm{Ca}^{2+}$ levels were assessed by Agilent Technologies 7700 Series ICP-MS equipment (Agilent Technologies, Santa Clara, CA, USA). Rf Power was $1550 \mathrm{~W}$, nebulizer gas flow rate was maintained at $1.05 \mathrm{~L} / \mathrm{min}$, and a samplespecific heating program was applied. Standard curves were plotted, and $\mathrm{Mg}^{2+}$ and $\mathrm{Ca}^{2+}$ levels were calculated as micrograms per liter wet tissue. 


\section{Other Measurements}

Glycosylated serum protein (GSP), blood urea nitrogen (BUN), creatinine (Cre), uric acid (UA), total cholesterol (CHO), triglyceride (TG), high-density lipoprotein (HLDL), and low-density lipoprotein cholesterol (LDL) levels were measured using a Hitachi 7600-010 Clinical Chemistry Analyzer (Hitachi, Tokyo, Japan) with the manufacturer's reagents, calibrators, and quality control (QC) products (Liquid Assay Multiqual Controls level 1, level 2, level 3 by Bio-Rad Laboratories, Inc.).

\section{Statistical Analysis}

Statistical analyses were performed using SPSS v21.0. Continuous variables are presented as mean \pm SE. Betweengroup comparisons were evaluated with Student's $t$ test. Associations between serum $\mathrm{Mg}^{2+}$ and $\mathrm{Ca}^{2+}$ levels as a continuous variable and biochemical parameters were assessed with Spearman's rank correlation analysis. All reported $p$ values are two-sided, and $p<0.05$ was considered significant.

\section{Results}

\section{Characteristics of Mice}

Characteristics of mice sacrificed after 2 weeks and 2 months of treatment with PBA or TUDCA are summarized in Table 1. At 2 weeks and 2 months, the DM mice had a significantly lower body weight ( 2 weeks, $23.6 \pm 0.78$ vs. $28.7 \pm 0.23 \mathrm{~g}$; 2 months, $23.1 \pm 0.25$ vs. $33.4 \pm 0.62 \mathrm{~g} ; P<0.05)$ and higher fasting blood glucose ( 2 weeks, $31.9 \pm 0.64$ vs. $7.2 \pm$ $0.45 \mathrm{mmol} / \mathrm{L} ; 2$ months, $33.7 \pm 0.61$ vs. $8.8 \pm 0.24 \mathrm{mmol} / \mathrm{L}$; $P<0.05)$ than the control mice. At 2 weeks and 2 months, $\mathrm{PBA}+\mathrm{DM}$ or TUDCA + DM mice had significantly higher body weight ( 2 weeks, PBA + DM $28.8 \pm 0.49 \mathrm{~g}$, TUDCA + DM $26.0 \pm 0.35 \mathrm{~g} ; 2$ months, PBA + DM $25.8 \pm 0.28 \mathrm{~g}$, TUDCA + DM $26.1 \pm 0.20 \mathrm{~g} ; P<0.05$ vs. DM mice) and significantly lower blood glucose (2 weeks, PBA + DM $26.4 \pm 0.47 \mathrm{mmol} / \mathrm{L}$, TUDCA + DM $21.4 \pm 0.84 \mathrm{mmol} / \mathrm{L}$; 2 months, PBA + DM $28.5 \pm 0.76 \mathrm{mmol} / \mathrm{L}$, TUDCA + DM $23.1 \pm 0.71 \mathrm{mmol} / \mathrm{L} ; P<0.05$ vs. DM mice) than the DM mice, although most values did not return to control levels.

At 2 months, the DM mice had significantly higher GSP $(475.4 \pm 19.2$ vs. $259.6 \pm 17.9 \mu \mathrm{mol} / \mathrm{L} ; P<0.05)$ and BUN $(16.8 \pm 0.59$ vs. $11.3 \pm 0.39 \mathrm{mmol} / \mathrm{L} ; P<0.05)$ levels than the control mice, but there were no significant differences between GSP and BUN levels in PBA + DM or TUDCA + DM mice compared to DM mice.

At 2 months, DM mice had significantly higher Cre (20.5 \pm 2.30 vs. $12.7 \pm 0.28 \mathrm{mmol} / \mathrm{L} ; P<0.05)$ levels than control mice, there was no significant difference between Cre levels in
TUDCA + DM mice compared to DM mice, but PBA + DM had significantly lower Cre $(13.3 \pm 0.94$ vs. $20.5 \pm$ $2.30 \mathrm{mmol} / \mathrm{L} ; P<0.05$ ) levels than the $\mathrm{DM}$ mice, with values similar to control levels.

At 2 months, DM mice had significantly higher CHO (6.9 \pm 0.60 vs. $3.9 \pm 0.16 \mathrm{mmol} / \mathrm{L} ; P<0.05)$ and TG $(6.9 \pm 0.74$ vs. $3.3 \pm 0.37 \mathrm{mmol} / \mathrm{L} ; P<0.05)$ levels than control mice, there were no significant differences between $\mathrm{CHO}$ and $\mathrm{TG}$ levels in PBA + DM mice compared to DM mice, but TUDCA + DM mice had significantly lower CHO (4.1 \pm $0.19 \mathrm{mmol} / \mathrm{L} ; P<0.05$ vs. DM mice) and TG (4.6 \pm $0.21 \mathrm{mmol} / \mathrm{L} ; P<0.05$ vs. DM mice) levels than the DM mice, with some values approaching control levels.

At 2 months, the DM mice had significantly higher LDL $(2.04 \pm 0.25$ vs. $0.81 \pm 0.05 \mathrm{mmol} / \mathrm{L} ; P<0.05)$ levels than control mice, but PBA + DM or TUDCA + DM had significantly lower LDL (PBA + DM, $1.39 \pm 0.15 \mathrm{mmol} / \mathrm{L}$; TUDCA $+\mathrm{DM} 0.76 \pm 0.03 \mathrm{mmol} / \mathrm{L} ; P<0.05$ vs. DM mice) levels than the DM mice, with some values approaching control levels.

\section{$\mathrm{Mg}^{2+}$ and $\mathrm{Ca}^{2+}$ Levels in the Heart, Liver, Kidney, Muscle, Spleen, and Serum}

$\mathrm{Mg}^{2+}$ levels in the heart, liver, kidney, muscle, spleen, and serum are summarized in Table 1 and Fig. 1. At 2 weeks and 2 months, the DM, PBA + DM, and TUDCA + DM mice had significantly lower cardiac $\mathrm{Mg}^{2+}(\mathrm{DM}, 235.1 \pm 14.9 \mathrm{mg} /$ $\mathrm{L} ; \mathrm{PBA}+\mathrm{DM}, 234.0 \pm 12.7 \mathrm{mg} / \mathrm{L}$; TUDCA + DM, $234.4 \pm$ $19.6 \mathrm{mg} / \mathrm{L}$ vs. $267.4 \pm 22.3 \mathrm{mg} / \mathrm{L}$ in 2 weeks; $\mathrm{DM}, 248.8 \pm$ $25.1 \mathrm{mg} / \mathrm{L} ;$ PBA + DM, $246.8 \pm 36.2 \mathrm{mg} / \mathrm{L} ;$ TUDCA + DM, $253.5 \pm 12.2 \mathrm{mg} / \mathrm{L}$ vs. $279.5 \pm 29.7 \mathrm{mg} / \mathrm{L}$ in 2 months; $P<0.05)$ levels compared to the control mice. At 2 weeks and 2 months, the DM mice had significantly lower hepatic $\mathrm{Mg}^{2+}$ (2 weeks, $314.4 \pm 35.0$ vs. $398.2 \pm 39.8 \mathrm{mg} / \mathrm{L} ; 2$ months, $319.4 \pm 77.9$ vs. $415.5 \pm 26.7 \mathrm{mg} / \mathrm{L} ; P<0.05)$ levels compared to the control mice; the TUDCA + DM mice had significantly higher hepatic $\mathrm{Mg}^{2+}$ (2 weeks, $392.4 \pm 22.6 \mathrm{mg} / \mathrm{L}$; 2 months, $387.4 \pm 32.7 \mathrm{mg} / \mathrm{L} ; P<0.05$ vs. DM mice) levels than the DM mice, with values similar to control levels; and there was no significant difference between hepatic $\mathrm{Mg}^{2+}$ levels in the PBA + DM mice compared to the DM mice. At 2 weeks and 2 months, the DM mice had significantly lower renal $\mathrm{Mg}^{2+}$ ( 2 weeks, $204.7 \pm 27.8$ vs. $241.0 \pm 23.5 \mathrm{mg} / \mathrm{L}$; 2 months, $186.9 \pm 14.6$ vs. $218.9 \pm 21.4 \mathrm{mg} / \mathrm{L} ; P<0.05$ ) levels compared to the control mice, and the TUDCA + DM mice and PBA + DM mice had significantly higher renal $\mathrm{Mg}^{2+}$ (TUDCA + DM, 248.8 $\pm 27.9 \mathrm{mg} / \mathrm{L} ; \mathrm{PBA}+\mathrm{DM}$, $249.3 \pm 26.6 \mathrm{mg} / \mathrm{L}$ in 2 weeks; TUDCA + DM, $227.5 \pm$ $34.0 \mathrm{mg} / \mathrm{L} ; \mathrm{PBA}+\mathrm{DM}, 237.1 \pm 43.5 \mathrm{mg} / \mathrm{L}$ in 2 months; $P<0.05$ vs. DM mice) levels than the DM mice, with values similar to control levels. At each time point, there were no significant differences in splenic or muscular $\mathrm{Mg}^{2+}$ levels in the DM, PBA + DM, TUDCA + DM, and control mice. At 


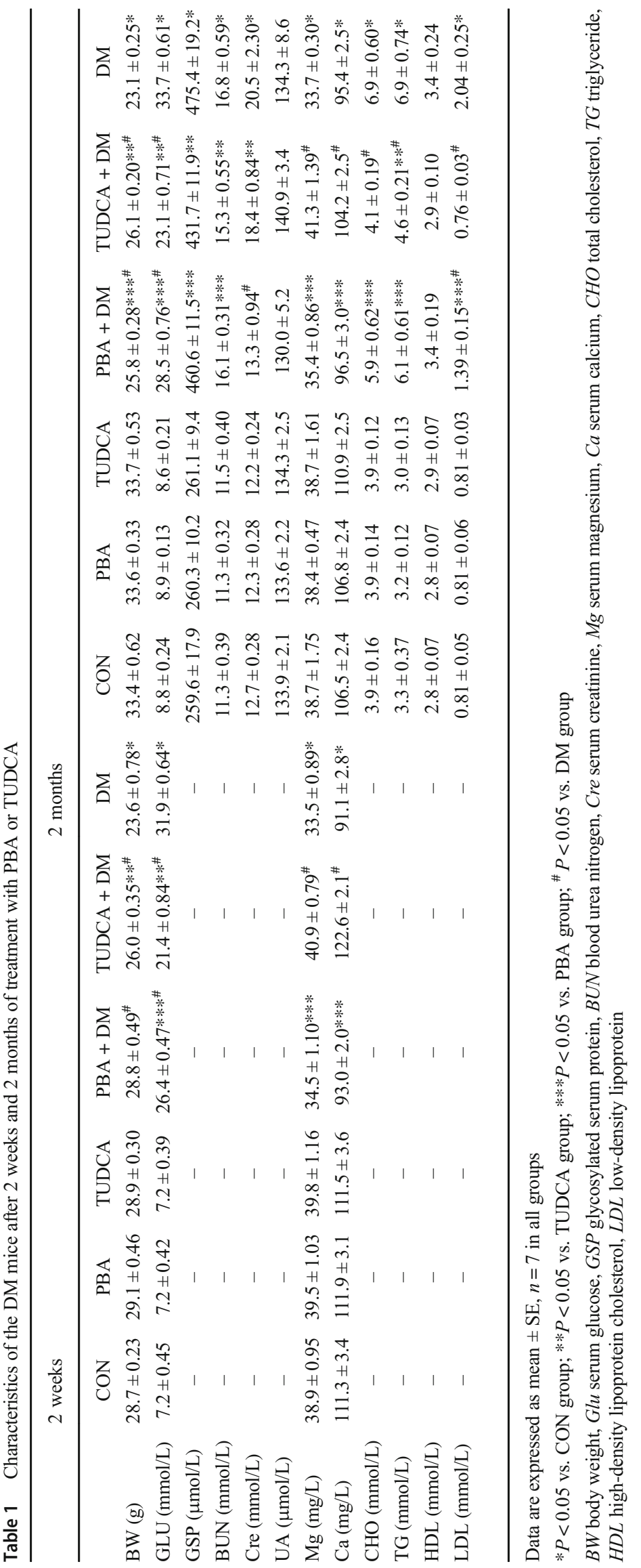


Fig. $1 \mathrm{Mg}^{2+}$ levels in the heart, liver, kidney, muscle, spleen, and serum of the DM mice. $\mathrm{Mg}^{2+}$ levels in the heart (a), liver (b), kidney (c), muscle (d), spleen (e), and serum (f) after 2 weeks and 2 months of treatment with PBA or TUDCA. Data are presented as mean $\pm \mathrm{SE}, n=7$ in all groups. CON non-diabetic control mice group, $D M$ diabetic mice group, $P B A+D M$ group of diabetic mice treated with PBA, TUDCA $+D M$ group of diabetic mice treated with TUDCA, $P B A$ group of non-diabetic control mice treated with PBA, TUDCA group of non-diabetic control mice treated with TUDCA a

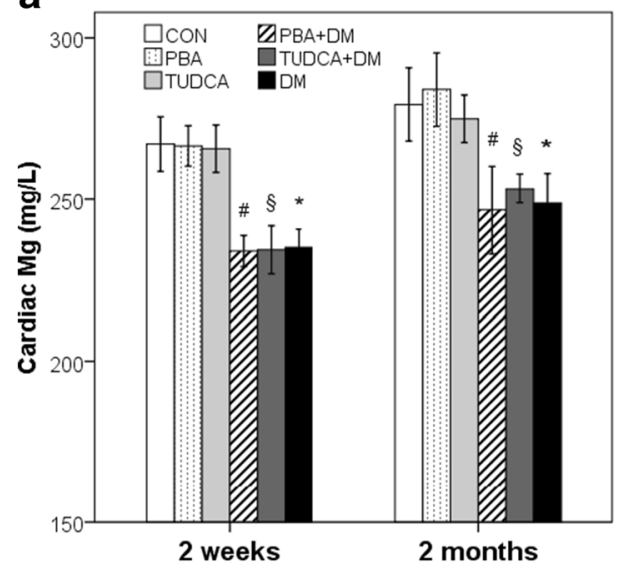

C

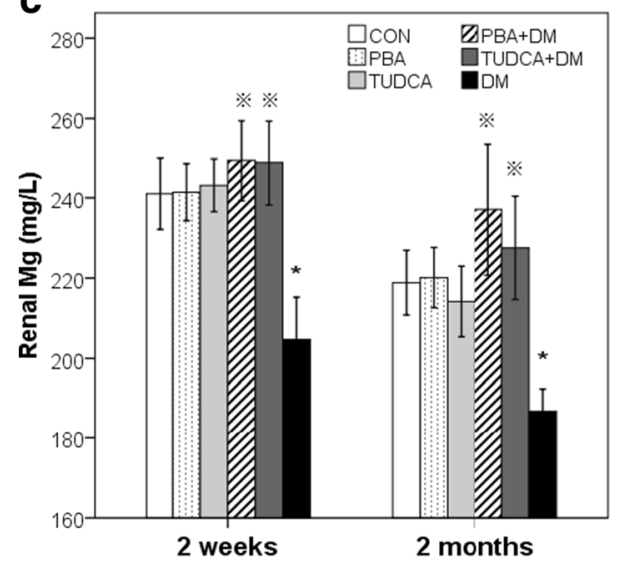

e

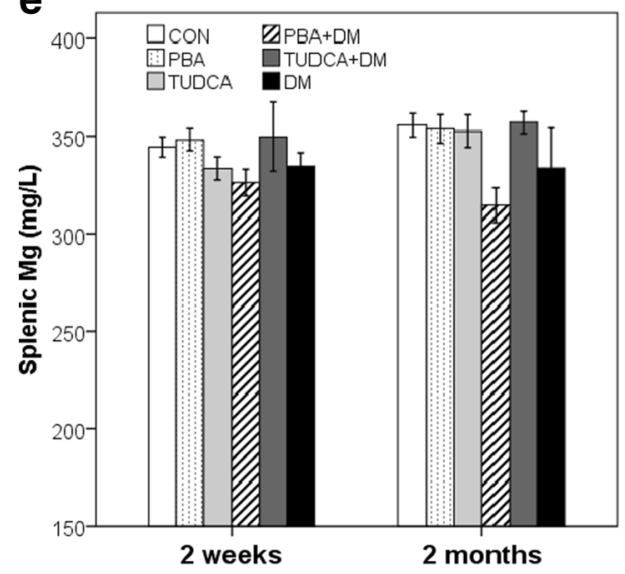

b

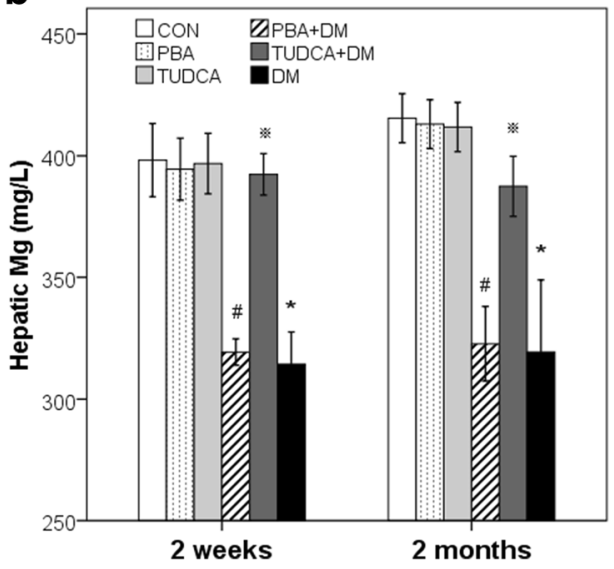

d

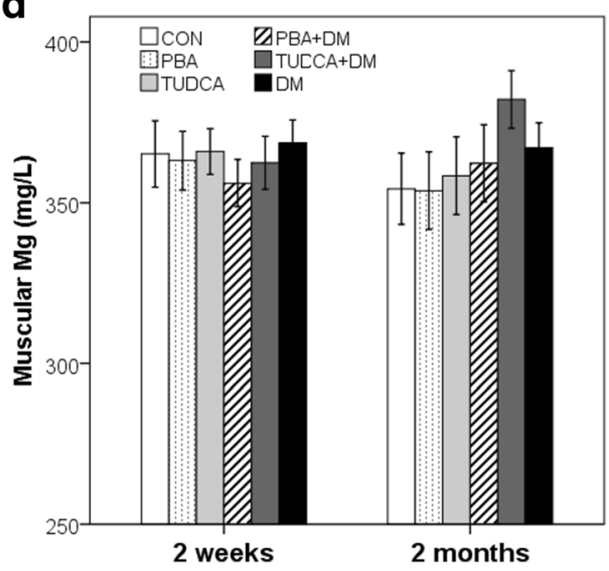

f

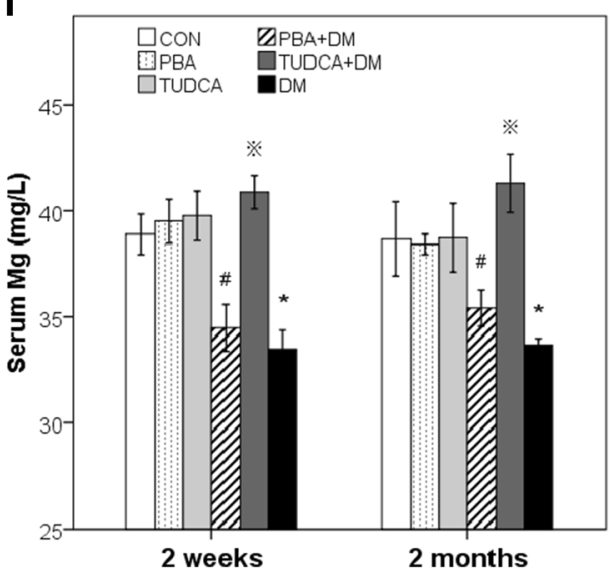

2 weeks and 2 months, the DM mice had significantly lower serum $\mathrm{Mg}^{2+}(2$ weeks, $33.5 \pm 0.89$ vs. $38.9 \pm 0.95 \mathrm{mg} / \mathrm{L}$; 2 months, $33.7 \pm 0.30$ vs. $38.7 \pm 1.75 \mathrm{mg} / \mathrm{L} ; P<0.05$ ) levels compared to the control mice, the TUDCA + DM mice had significantly higher serum $\mathrm{Mg}^{2+}$ ( 2 weeks, $40.9 \pm 0.79 \mathrm{mg} / \mathrm{L}$; 2 months, $41.3 \pm 1.39 \mathrm{mg} / \mathrm{L} ; P<0.05$ vs. DM mice) levels than the DM mice, with values similar to control levels; and there were no significant differences between serum $\mathrm{Mg}^{2+}$ levels in the PBA + DM mice compared to the DM mice.
$\mathrm{Ca}^{2+}$ levels in the heart, liver, kidney, muscle, spleen, and serum are summarized in Table 1 and Fig. 2. At each time point, there were no significant differences in cardiac $\mathrm{Ca}^{2+}$ levels in the DM, PBA + DM, TUDCA + DM, and control mice. At 2 weeks, there were no significant differences in hepatic $\mathrm{Ca}^{2+}$ levels in the DM, PBA + DM, TUDCA + DM, and control mice, but at 2 months, hepatic $\mathrm{Ca}^{2+}(24.1 \pm 3.1 \mathrm{vs}$. $29.0 \pm 2.8 \mathrm{mg} / \mathrm{L} ; P<0.05$ ) levels in the TUDCA + DM mice were significantly lower than the control mice. At 2 weeks and 2 months, renal $\mathrm{Ca}^{2+}$ ( 2 weeks, $42.6 \pm 2.3$ vs. $32.3 \pm 7.2 \mathrm{mg} / \mathrm{L}$; 
Fig. $2 \mathrm{Ca}^{2+}$ levels in the heart, liver, kidney, muscle, spleen, and serum of the DM mice. $\mathrm{Ca}^{2+}$ levels in the heart (a), liver (b), kidney (c), muscle (d), spleen (e), and serum (f) after 2 weeks and 2 months of treatment with PBA or TUDCA. Data are presented as mean $\pm \mathrm{SE}, n=7$ in all groups
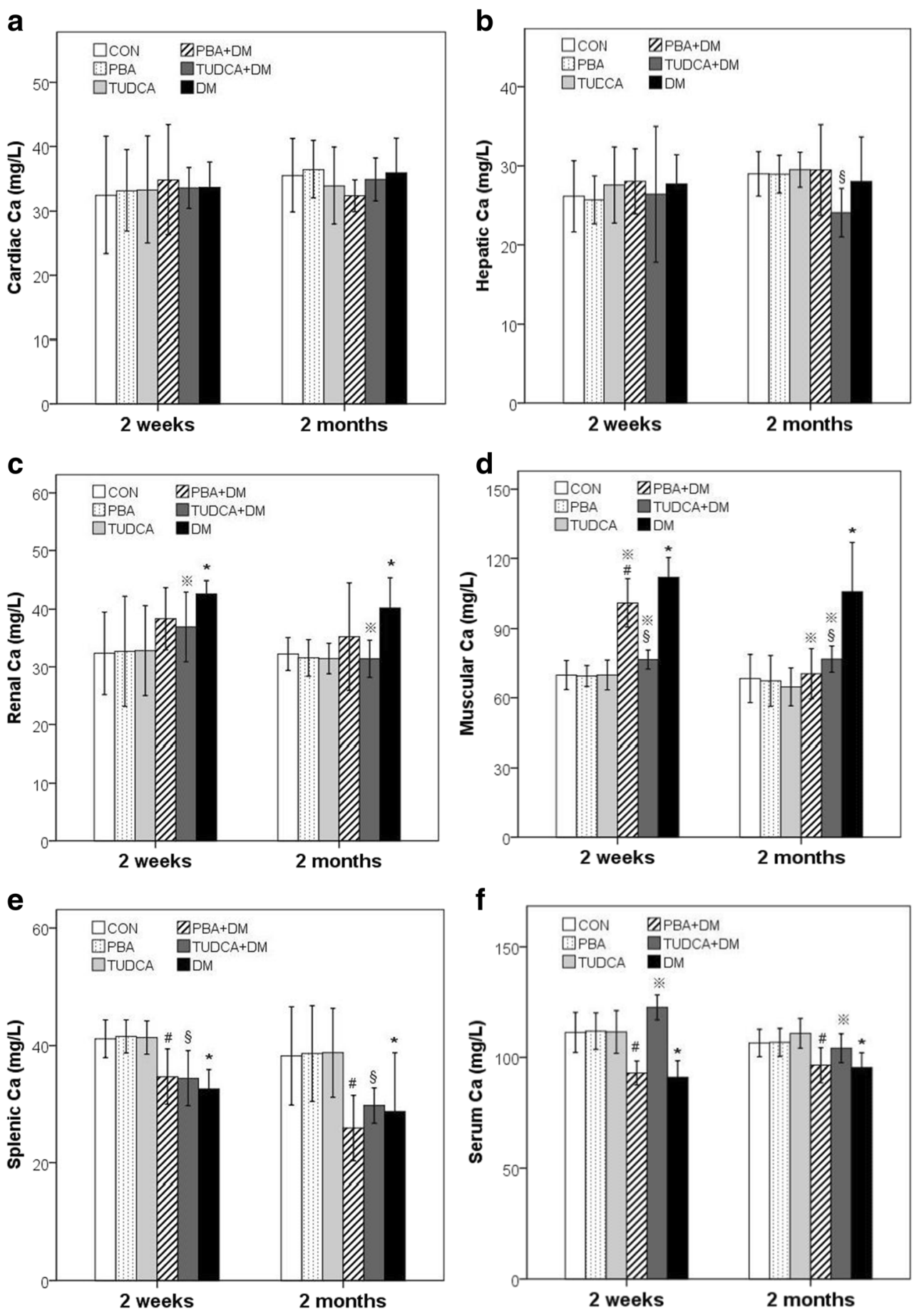

2 months, $40.2 \pm 5.2$ vs. $32.2 \pm 2.9 \mathrm{mg} / \mathrm{L} ; P<0.05)$ levels in the DM mice were significantly higher than the control mice, and renal $\mathrm{Ca}^{2+}$ (2 weeks, $36.9 \pm 6.0 \mathrm{mg} / \mathrm{L} ; 2$ months, $31.4 \pm$ $3.2 \mathrm{mg} / \mathrm{L} ; P<0.05$ vs. DM mice) levels in the TUDCA + DM were significantly lower than the DM mice, with values similar to control levels. At 2 weeks and 2 months, muscular $\mathrm{Ca}^{2+}$ ( 2 weeks, $112.1 \pm 8.2$ vs. $69.9 \pm 6.3 \mathrm{mg} / \mathrm{L} ; 2$ months, $106.0 \pm$ 20.9 vs. $68.4 \pm 10.4 \mathrm{mg} / \mathrm{L} ; P<0.05)$ levels in the DM mice were significantly higher than the control mice, and muscular
$\mathrm{Ca}^{2+}(\mathrm{PBA}+\mathrm{DM}, 101.1 \pm 10.4 \mathrm{mg} / \mathrm{L} ; \mathrm{TUDCA}+\mathrm{DM}, 76.6 \pm$ $4.1 \mathrm{mg} / \mathrm{L}$ in 2 weeks; PBA + DM, $70.4 \pm 10.9 \mathrm{mg} / \mathrm{L}$; TUDCA $+\mathrm{DM}, 76.8 \pm 5.7 \mathrm{mg} / \mathrm{L}$ in 2 months) levels in the PBA + DM and TUDCA + DM mice were significantly lower than the DM mice, although most values did not return to control levels. At each time point, the DM, PBA + DM, and TUDCA + DM mice had significantly lower splenic $\mathrm{Ca}^{2+}$ (DM, 32.6 $\pm 3.3 \mathrm{mg} / \mathrm{L} ; \mathrm{PBA}+\mathrm{DM}, 34.7 \pm 4.7 \mathrm{mg} / \mathrm{L}$; TUDCA + DM, $34.5 \pm 4.7 \mathrm{mg} / \mathrm{L}$ vs. $41.2 \pm 3.2 \mathrm{mg} / \mathrm{L}$ in 
2 weeks; DM, $28.8 \pm 10.0 \mathrm{mg} / \mathrm{L}$; PBA + DM, $25.9 \pm 5.6 \mathrm{mg} /$ $\mathrm{L}$; TUDCA + DM, $29.8 \pm 3.0 \mathrm{mg} / \mathrm{L}$ vs. $38.3 \pm 8.4 \mathrm{mg} / \mathrm{L}$ in 2 months; $P<0.05)$ levels than the control mice. At 2 weeks and 2 months, serum $\mathrm{Ca}^{2+}(2$ weeks, $91.1 \pm 2.8$ vs. $111.3 \pm$ $3.4 \mathrm{mg} / \mathrm{L} ; 2$ months, $95.4 \pm 2.5$ vs. $106.5 \pm 2.4 \mathrm{mg} / \mathrm{L}$; $P<0.05)$ levels in the DM mice were significantly lower than the control mice; serum $\mathrm{Ca}^{2+}(2$ weeks, $122.6 \pm 2.1 \mathrm{mg} / \mathrm{L}$; 2 months, $104.2 \pm 2.5 \mathrm{mg} / \mathrm{L} ; P<0.05)$ levels in the TUDCA + DM mice were significantly higher than the DM mice, with values similar to control levels; and there were no significant differences between serum $\mathrm{Ca}^{2+}$ levels in PBA + DM mice compared to DM mice.

\section{Correlation of $\mathrm{Mg}^{2+}$ and $\mathrm{Ca}^{2+}$ Levels in the Heart, Liver, Kidney, Muscle, Spleen, and Serum}

Correlations between $\mathrm{Mg}^{2+}$ and $\mathrm{Ca}^{2+}$ levels in the heart, liver, kidney, muscle, spleen, and serum of the DM mice after 2 weeks and 2 months of treatment with PBA or TUDCA are summarized in Tables 2 and 3 Fig. $3 . \mathrm{Mg}^{2+}$ levels were positively correlated with $\mathrm{Ca}^{2+}$ levels in the heart, liver, kidney, muscle, spleen, and serum in all groups of mice at 2 weeks and 2 months, except in the liver of the PBA + DM or TUDCA + DM mice at both time points, and the heart of the TUDCA + DM mice at 2 weeks.

\section{Discussion}

This study established and characterized a mouse model of T1D and investigated the effect of TUDCA and PBA on $\mathrm{Mg}^{2+}$ and $\mathrm{Ca}^{2+}$ metabolism in these mice. Findings showed T1D mice had decreased body weight and increased blood glucose at 2 weeks and 2 months after chaperone or vehicle administration was initiated, and GSP, BUN, Cre, CHO, TG, and LDL levels were significantly increased in T1D mice at 2 months. PBA or TUDCA administration attenuated the changes in body weight and blood glucose in T1D mice at 2 weeks and 2 months. PBA administration attenuated the changes in Cre levels, and TUDCA attenuated the changes in $\mathrm{CHO}, \mathrm{TG}$, and LDL levels at 2 months.

In addition, the present study comprehensively evaluates $\mathrm{Mg}^{2+}$ and $\mathrm{Ca}^{2+}$ levels in the heart, liver, kidney, muscle, spleen, and serum of T1D mice. Findings showed T1D mice experienced alterations in $\mathrm{Mg}^{2+}$ and $\mathrm{Ca}^{2+}$ homeostasis; $\mathrm{Mg}^{2+}$ levels were significantly decreased in the heart, liver, kidney, and serum of T1D mice compared to controls. $\mathrm{Ca}^{2+}$ levels were significantly decreased in the spleen and serum of T1D mice compared to controls, but significantly increased in the kidney and muscle.

$\mathrm{Mg}^{2+}$ and $\mathrm{Ca}^{2+}$ are important micronutrients that are involved in several pathophysiological mechanisms. A deficiency in $\mathrm{Mg}^{2+}$ in T1D may result from insufficient dietary intake, decreased absorption in the gastrointestinal tract [17], altered reabsorption in the kidney due to hyperglycemia and hypersthenuria [18], and/or redistribution in the body due to metabolic and/or acid-base disorders [18]. Diabetes is characterized by a negative $\mathrm{Mg}^{2+}$ balance, which may manifest as hypocalcaemia, hypokalemia, and cardiac and neurological dysfunction [19]. $\mathrm{Ca}^{2+}$ homeostasis may be disrupted by obesity, which influences cellular $\mathrm{Ca}^{2+}$ flux between the cytosol and organelles [6]. $\mathrm{Ca}^{2+}$ regulates insulin and glucagon secretion and the control of blood glucose [6]. $\mathrm{Ca}^{2+}$ plays an important role in muscle contraction; therefore, altered cellular $\mathrm{Ca}^{2+}$ levels can impact the heart and skeletal muscle [6]. Further, $\mathrm{Ca}^{2+}$ is essential for adequate hepatic glucose production, lipogenesis, inflammation, and other critical metabolic processes [6]. Findings from the present study suggest a

Table 2 Correlations between $\mathrm{Mg}^{2+}$ and $\mathrm{Ca}^{2+}$ levels in the heart, liver, kidney, muscle, spleen, and serum of diabetic mice after 2 weeks of treatment with PBA or TUDCA

\begin{tabular}{|c|c|c|c|c|c|c|c|c|c|c|c|c|}
\hline & \multicolumn{12}{|l|}{$\mathrm{Mg}$} \\
\hline & \multicolumn{2}{|l|}{$\mathrm{CON}$} & \multicolumn{2}{|l|}{ PBA } & \multicolumn{2}{|c|}{ TUDCA } & \multicolumn{2}{|c|}{$\mathrm{PBA}+\mathrm{DM}$} & \multicolumn{2}{|c|}{ TUDCA+DM } & \multicolumn{2}{|l|}{ DM } \\
\hline & $r$ & $P$ & $r$ & $P$ & $r$ & $P$ & $r$ & $P$ & $r$ & $P$ & $r$ & $P$ \\
\hline $\mathrm{H}-\mathrm{Ca}$ & 0.937 & $0.002 *$ & 0.893 & $0.007^{*}$ & 0.857 & $0.014 *$ & 0.857 & $0.014 *$ & 0.214 & 0.645 & 0.964 & $0.000 *$ \\
\hline $\mathrm{L}-\mathrm{Ca}$ & 0.857 & $0.014 *$ & 0.786 & $0.036^{*}$ & 0.929 & $0.003 *$ & 0.036 & 0.939 & 0.432 & 0.333 & 0.883 & $0.008 *$ \\
\hline $\mathrm{K}-\mathrm{Ca}$ & 0.786 & $0.036^{*}$ & 0.821 & $0.023 *$ & 0.857 & $0.014 *$ & 0.857 & $0.014 *$ & 0.893 & $0.007 *$ & 0.857 & $0.014 *$ \\
\hline $\mathrm{M}-\mathrm{Ca}$ & 0.883 & $0.008 *$ & 0.857 & $0.014 *$ & 0.857 & $0.014 *$ & 0.821 & $0.023 *$ & 0.857 & $0.014 *$ & 0.857 & $0.014 *$ \\
\hline $\mathrm{P}-\mathrm{Ca}$ & 0.821 & $0.023 *$ & 0.929 & $0.003 *$ & 0.929 & $0.003 *$ & 0.857 & $0.014 *$ & 0.821 & $0.023^{*}$ & 0.857 & $0.014 *$ \\
\hline $\mathrm{S}-\mathrm{Ca}$ & 0.786 & $0.036^{*}$ & 0.857 & $0.014^{*}$ & 0.929 & $0.003 *$ & 0.821 & $0.023 *$ & 0.821 & $0.023 *$ & 0.847 & $0.016^{*}$ \\
\hline
\end{tabular}

$H$-Ca calcium level in the heart, $L-C a$ calcium level in the liver, $K$ - $C a$ calcium level in the kidney, $M$ - $C a$ calcium level in the muscle, $P$ - $C a$ calcium level in the spleen, $\mathrm{S}-\mathrm{Ca}$ calcium level in serum

$* P<0.05$ for the correlation 
Table 3 Correlations between $\mathrm{Mg}^{2+}$ and $\mathrm{Ca}^{2+}$ levels in the heart, liver, kidney, muscle, spleen, and serum of diabetic mice after 2 months of treatment with PBA or TUDCA

\begin{tabular}{|c|c|c|c|c|c|c|c|c|c|c|c|c|}
\hline & \multicolumn{12}{|l|}{$\mathrm{Mg}$} \\
\hline & \multicolumn{2}{|l|}{$\mathrm{CON}$} & \multicolumn{2}{|l|}{ PBA } & \multicolumn{2}{|c|}{ TUDCA } & \multicolumn{2}{|c|}{$\mathrm{PBA}+\mathrm{DM}$} & \multicolumn{2}{|c|}{ TUDCA+DM } & \multicolumn{2}{|l|}{$\mathrm{DM}$} \\
\hline & $r$ & $P$ & $r$ & $P$ & $r$ & $P$ & $r$ & $P$ & $r$ & $P$ & $r$ & $P$ \\
\hline $\mathrm{H}-\mathrm{Ca}$ & 0.893 & $0.007 *$ & 0.857 & $0.014 *$ & 0.929 & $0.003 *$ & 0.929 & $0.003 *$ & 0.857 & $0.014^{*}$ & 0.873 & $0.010^{*}$ \\
\hline $\mathrm{L}-\mathrm{Ca}$ & 0.929 & $0.003 *$ & 0.821 & $0.023 *$ & 0.821 & $0.023 *$ & 0.357 & 0.432 & 0.429 & 0.337 & 0.893 & $0.007 *$ \\
\hline $\mathrm{K}-\mathrm{Ca}$ & 0.857 & $0.014 *$ & 0.893 & $0.007 *$ & 0.893 & $0.007 *$ & 0.893 & $0.007 *$ & 0.821 & $0.023 *$ & 0.857 & $0.014 *$ \\
\hline $\mathrm{M}-\mathrm{Ca}$ & 0.929 & $0.003 *$ & 0.786 & $0.036^{*}$ & 0.821 & $0.023 *$ & 0.857 & $0.014 *$ & 0.937 & $0.002 *$ & 0.901 & $0.006^{*}$ \\
\hline $\mathrm{P}-\mathrm{Ca}$ & 0.821 & $0.023^{*}$ & 0.857 & $0.014 *$ & 0.857 & $0.014 *$ & 0.857 & $0.014 *$ & 0.857 & $0.014 *$ & 0.929 & $0.003^{*}$ \\
\hline $\mathrm{S}-\mathrm{Ca}$ & 0.775 & $0.041 *$ & 0.857 & $0.014 *$ & 0.821 & $0.023 *$ & 0.857 & $0.014 *$ & 0.857 & $0.014 *$ & 0.893 & $0.007 *$ \\
\hline
\end{tabular}

$H$ - $C a$ calcium level in the heart, $L-C a$ calcium level in the liver, $K$-Ca calcium level in the kidney, $M$ - $C a$ calcium level in the muscle, $P$ - $C a$ calcium level in the spleen, $\mathrm{S}-\mathrm{Ca}$ calcium level in serum

$* P<0.05$ for the correlation

potential role for therapeutic strategies targeted at maintaining $\mathrm{Mg}^{2+}$ and $\mathrm{Ca}^{2+}$ homeostasis in tissues and serum in the management of diabetes.

The present study assessed the relationship between $\mathrm{Mg}^{2+}$ and $\mathrm{Ca}^{2+}$ levels in tissues and serum of T1D mice. Findings showed that $\mathrm{Mg}^{2+}$ levels in the heart, liver, kidney, muscle, spleen, and serum were positively correlated with $\mathrm{Ca}^{2+}$ levels in T1D and control mice at 2 weeks and 2 months after chaperone or vehicle administration was initiated, but not in T1D mice administered PBA or TUDCA. These findings are in accordance with our previous study, in which serum $\mathrm{Mg}^{2+}$ levels were positively correlated with $\mathrm{Ca}^{2+}$ levels in individuals with T2D [2], and urinary $\mathrm{Mg}^{2+}$ levels were positively correlated with urinary $\mathrm{Ca}^{2+}$ in controls and individuals with impaired glucose tolerance or T2D [2]. In other studies, there were significant positive correlations between $\mathrm{Mg}^{2+}$ and $\mathrm{Ca}^{2+}$ urinary excretion rates, clearance, and excretion fractions in individuals with diabetes in Nigeria [20], and serum $\mathrm{Mg}^{2+}$ and $\mathrm{Ca}^{2+}$ levels and the interaction between serum $\mathrm{Mg}^{2+}$ and $\mathrm{Ca}^{2+}$ levels $\left(\mathrm{Mg}^{2+} \times \mathrm{Ca}^{2+}\right)$ had significant negative correlations with eGFR [17] in individuals with T2D; $\left(\mathrm{Mg}^{2+} \times \mathrm{Ca}^{2+}\right)$ had the strongest correlation with eGFR [17]. Taken together, these data imply positive associations and possible regulatory effects between tissue and serum $\mathrm{Mg}^{2+}$ and $\mathrm{Ca}^{2+}$ levels in healthy individuals and those with diabetes. Further animal experiments and clinical investigations are required to elucidate the underlying mechanisms and relevance of these observations.

Chemical or pharmaceutical chaperones, including PBA and TUDCA, are a group of low molecular weight compounds that can stabilize protein conformation, improve the folding capacity of the ER, and facilitate the trafficking of mutant proteins [21]. TUDCA is a taurine-conjugated bile acid that has been safely used in Traditional Chinese Medicine (dried bile from adult black bears) and in the Western World to treat biliary and liver diseases [22]. PBA was approved by the US Food and Drug Administration as an ammonia scavenger for the treatment of urea-cycle disorders
Fig. 3 Correlation between serum $\mathrm{Mg}^{2+}$ and $\mathrm{Ca}^{2+}$ levels in the DM mice. Correlations between serum $\mathrm{Mg}^{2+}$ and serum $\mathrm{Ca}^{2+}$ levels after 2 weeks $(r=0.898, P<0.001$, a) and 2 months $(r=0.796$, $P<0.001, \mathbf{b})$ of treatment with PBA or TUDCA a

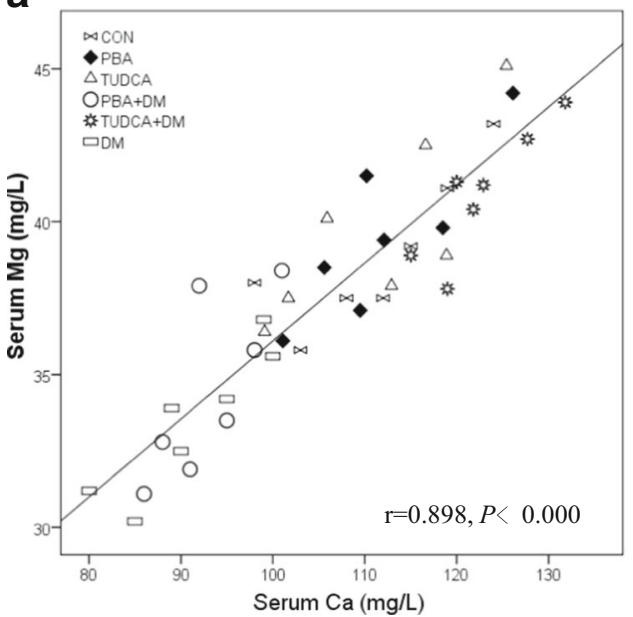

b

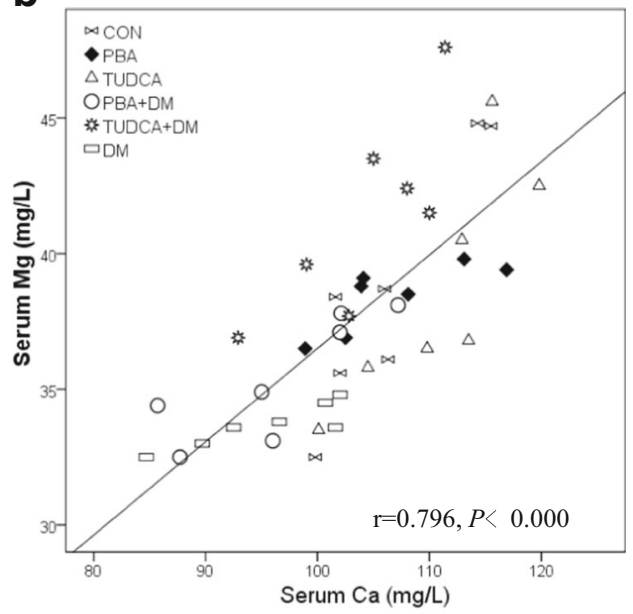


and has been investigated in clinical trials in patients with thalassemia and cystic fibrosis [15]. Evidence suggests that PBA and TUDCA can confer antiapoptotic, anti-inflammatory, antioxidant and immunomodulation effects [22, 23], enhance ER adaptability, and prevent insulin resistance [21, 22].

In the present study, PBA restored renal $\mathrm{Mg}^{2+}$ and muscular $\mathrm{Ca}^{2+}$ to control levels in the DM mice 2 weeks and 2 months after chaperone or vehicle administration was initiated, and TUDCA restored hepatic, renal, and serum $\mathrm{Mg}^{2+}$ and renal and serum $\mathrm{Ca}^{2+}$ to control levels. This study confirmed that molecular chaperones have a role in the regulation of micronutrients in a mouse model of T1D.

These findings are in accordance with several previous reports. In a mouse model of pulmonary hypertension, PBA reversed the hypoxia-induced alterations in mitochondrial $\mathrm{Ca}^{2+}$ levels and the activity of $\mathrm{Ca}^{2+}$-sensitive mitochondrial enzymes in pulmonary artery smooth muscle, thereby preventing and reversing pulmonary hypertension [24]. In Leishmania parasites, PBA inhibited $\mathrm{Ca}^{2+}$-induced mitochondrial toxicity and inhibited DNA degradation, phosphatidylserine exposure, and apoptosis [25]. In bile duct ligated-rats that had undergone vagotomy, TUDCA prevented $\mathrm{Ca}^{2+}$-induced apoptosis and the loss of proliferative and functional responses [26]. In obese mice, TUDCA regulated intracellular calmodulin and prevented damage to the myocardium [22].

Interestingly, in the present study, the effect of DM, PBA, and TUDCA on $\mathrm{Mg}^{2+}$ and $\mathrm{Ca}^{2+}$ levels in T1D mice varied according to the tissue tested. This may because the number of mitochondria, ER, and ion exchange pumps, and/or the concentrations of micronutrients vary across tissues.

\section{Conclusions}

In conclusion, to the author's knowledge, this is first study to systematically investigate the effects of PBA and TUDCA on $\mathrm{Mg}^{2+}$ and $\mathrm{Ca}^{2+}$ metabolism in tissues and serum in a mouse model of T1D. Findings showed that (1) $\mathrm{Mg}^{2+}$ levels in the heart, liver, kidney, and serum and $\mathrm{Ca}^{2+}$ levels in the spleen and serum of T1D mice were significantly decreased compared to controls, while $\mathrm{Ca}^{2+}$ levels in the kidney and muscle were significantly increased; (2) $\mathrm{Mg}^{2+}$ and $\mathrm{Ca}^{2+}$ levels in the heart, liver, kidney, muscle, spleen and serum were positively correlated in control and T1D mice at 2 weeks and 2 months after chaperone or vehicle administration was initiated; (3) PBA restored renal $\mathrm{Mg}^{2+}$ levels to normal values at 2 weeks and 2 months after chaperone or vehicle administration was initiated and muscular $\mathrm{Ca}^{2+}$ levels to normal values at 2 months, TUDCA restored hepatic, renal, and serum $\mathrm{Mg}^{2+}$ levels and renal and serum $\mathrm{Ca}^{2+}$ levels to normal values at 2 weeks and 2 months after chaperone or vehicle administration was initiated. Further research is required to investigate the underlying mechanisms by which chaperones regulate micronutrients.

Funding The data cited from the laboratories of authors were supported in part by grants from the National Science Foundation of China (no. 81501839, to Dr. Qi Zhou), the Scientific and Technological "13th Five-Year Plan" Project of Jilin Provincial Department of Education (no. JJKH20180214KJ, to Dr. Qi Zhou.), Jilin Province Health and Technology Innovation Development Program (no. 2017J071, to Dr. Jiancheng $\mathrm{Xu}$ ], and the Jilin Science and Technology Development Program (no. 20170623092TC-09, to Dr. Jiancheng Xu; no. 20160101091JC, to Dr. Jiancheng Xu; no. 20150414039GH, to Dr. Jiancheng $\mathrm{Xu}$ ), and the Norman Bethune Program of Jilin University (no. 2012223, to Dr. Jiancheng Xu).

\section{Compliance with Ethical Standards}

Conflict of Interest The authors declare that they have no competing interests.

Open Access This article is distributed under the terms of the Creative Commons Attribution 4.0 International License (http:// creativecommons.org/licenses/by/4.0/), which permits unrestricted use, distribution, and reproduction in any medium, provided you give appropriate credit to the original author(s) and the source, provide a link to the Creative Commons license, and indicate if changes were made.

\section{References}

1. Low WY, Lee YK, Samy AL (2015) Non-communicable diseases in the Asia-Pacific region: prevalence, risk factors and communitybased prevention. Int J Occup Med Environ Health 28(1):20-26. https://doi.org/10.2478/s13382-014-0326-0

2. Xu J, Xu W, Yao H, Sun W, Zhou Q, Cai L (2013) Associations of serum and urinary magnesium with the pre-diabetes, diabetes and diabetic complications in the Chinese northeast population. PLoS One 8(2):e56750. https://doi.org/10.1371/journal.pone.0056750

3. DiMeglio LA, Evans-Molina C, Oram RA (2018) Type 1 diabetes. Lancet 391(10138):2449-2462. https://doi.org/10.1016/S01406736(18)31320-5

4. Zhou Q, Wang D, Xu J, Chi B (2016) Effect of Tauroursodeoxycholic acid and 4-phenylbutyric acid on metabolism of copper and zinc in type 1 diabetic mice model. Biol Trace Elem Res 170(2):348-356. https://doi.org/10.1007/s12011-0150474-5

5. Veronese N, Watutantrige-Fernando S, Luchini C, Solmi M, Sartore G, Sergi G, Manzato E, Barbagallo M, Maggi S, Stubbs B (2016) Effect of magnesium supplementation on glucose metabolism in people with or at risk of diabetes: a systematic review and metaanalysis of double-blind randomized controlled trials. Eur J Clin Nutr 70(12):1463. https://doi.org/10.1038/ejen.2016.209

6. Arruda AP, Hotamisligil GS (2015) Calcium homeostasis and organelle function in the pathogenesis of obesity and diabetes. Cell Metab 22(3):381-397. https://doi.org/10.1016/j.cmet.2015.06.010

7. Barbagallo M, Dominguez LJ (2015) Magnesium and type 2 diabetes. World J Diabetes 6(10):1152-1157. https://doi.org/10.4239/ wjd.v6.i10.1152

8. Fang X, Han H, Li M, Liang C, Fan Z, Aaseth J, He J, Montgomery S, Cao Y (2016) Dose-response relationship between dietary magnesium intake and risk of type 2 diabetes mellitus: a systematic 
review and meta-regression analysis of prospective cohort studies. Nutrients 8(11). https://doi.org/10.3390/nu8110739

9. Guerrero-Romero F, Rodriguez-Moran M (2014) Oral magnesium supplementation: an adjuvant alternative to facing the worldwide challenge of type 2 diabetes? Cir Cir 82(3):282-289

10. Wongdee K, Krishnamra N, Charoenphandhu N (2017) Derangement of calcium metabolism in diabetes mellitus: negative outcome from the synergy between impaired bone turnover and intestinal calcium absorption. J Physiol Sci 67(1):71-81. https:// doi.org/10.1007/s12576-016-0487-7

11. Xu J, Wang G, Wang Y, Liu Q, Xu W, Tan Y, Cai L (2009) Diabetes- and angiotensin II-induced cardiac endoplasmic reticulum stress and cell death: metallothionein protection. J Cell Mol Med 13(8A):1499-1512. https://doi.org/10.1111/j.1582-4934. 2009.00833.x

12. Xu J, Zhou Q, Xu W, Cai L (2012) Endoplasmic reticulum stress and diabetic cardiomyopathy. Exp Diabetes Res 2012:827971. https://doi.org/10.1155/2012/827971

13. Panda DK, Bai X, Sabbagh Y, Zhang Y, Zaun HC, Karellis A, Koromilas AE, Lipman ML, Karaplis AC (2018) Defective interplay between mTORC1 activity and endoplasmic reticulum stressunfolded protein response in uremic vascular calcification. Am J Physiol Renal Physiol 314(6):F1046-F1061. https://doi.org/10. 1152/ajprenal.00350.2017

14. Chen X, Li K, Zhao G (2018) Propofol inhibits HeLa cells by impairing autophagic flux via AMP-activated protein kinase (AMPK) activation and endoplasmic reticulum stress regulated by calcium. Med Sci Monit 24:2339-2349

15. Zhu Q, Guo R, Liu C, Fu D, Liu F, Hu J, Jiang H (2015) Endoplasmic reticulum stress-mediated apoptosis contributing to high glucose-induced vascular smooth muscle cell calcification. J Vasc Res 52(5):291-298. https://doi.org/10.1159/000442980

16. Ma L, Chu W, Chai J, Shen C, Li D, Wang X (2017) ER stress and subsequent activated calpain play a pivotal role in skeletal muscle wasting after severe burn injury. PLoS One 12(10):e0186128. https://doi.org/10.1371/journal.pone.0186128

17. Pham PC, Pham PM, Pham PT (2012) Patients with diabetes mellitus type 2 and hypomagnesemia may have enhanced glomerular filtration via hypocalcemia. Clin Nephrol 78(6):442448. https://doi.org/10.5414/CN107525

18. Mooren FC (2015) Magnesium and disturbances in carbohydrate metabolism. Diabetes Obes Metab 17(9):813-823. https://doi.org/ 10.1111/dom.12492

19. Swaminathan R (2003) Magnesium metabolism and its disorders. Clin Biochem Rev 24(2):47-66

20. Olukoga AO, Adewoye HO, Erasumus RT (1989) Renal excretion of magnesium and calcium in diabetes mellitus. Cent Afr J Med 35(4):378-383

21. Ozcan U, Yilmaz E, Ozcan L, Furuhashi M, Vaillancourt E, Smith RO, Gorgun CZ, Hotamisligil GS (2006) Chemical chaperones reduce ER stress and restore glucose homeostasis in a mouse model of type 2 diabetes. Science 313(5790):1137-1140. https://doi.org/ 10.1126/science. 1128294

22. Ceylan-Isik AF, Sreejayan N, Ren J (2011) Endoplasmic reticulum chaperon tauroursodeoxycholic acid alleviates obesity-induced myocardial contractile dysfunction. J Mol Cell Cardiol 50(1):107116. https://doi.org/10.1016/j.yjmcc.2010.10.023

23. Ikegami T, Matsuzaki Y (2008) Ursodeoxycholic acid: mechanism of action and novel clinical applications. Hepatol Res 38(2):123131. https://doi.org/10.1111/j.1872-034X.2007.00297.x

24. Dromparis P, Paulin R, Stenson TH, Haromy A, Sutendra G, Michelakis ED (2013) Attenuating endoplasmic reticulum stress as a novel therapeutic strategy in pulmonary hypertension. Circulation 127(1):115-125. https://doi.org/10.1161/ CIRCULATIONAHA.112.133413

25. Dolai S, Pal S, Yadav RK, Adak S (2011) Endoplasmic reticulum stress-induced apoptosis in Leishmania through $\mathrm{Ca} 2+-$ dependent and caspase-independent mechanism. J Biol Chem 286(15):1363813646. https://doi.org/10.1074/jbc.M110.201889

26. Marzioni M, Francis H, Benedetti A, Ueno Y, Fava G, Venter J, Reichenbach R, Mancino MG, Summers R, Alpini G, Glaser S (2006) Ca2+-dependent cytoprotective effects of ursodeoxycholic and tauroursodeoxycholic acid on the biliary epithelium in a rat model of cholestasis and loss of bile ducts. Am J Pathol 168(2): 398-409. https://doi.org/10.2353/ajpath.2006.050126 